\title{
Puma (Puma concolor) predation on tapir (Tapirus terrestris)
}

\author{
Fernando Cesar Cascelli Azevedo ${ }^{1,5}$, Vagner Canuto ${ }^{2}$, Fernanda Souza ${ }^{3}$ \& Cynthia Elisa Widmer ${ }^{4}$ \\ ${ }^{1}$ Universidade Federal de São João del-Rei, Departamento de Ciências Naturais, \\ Praça Dom Helvécio, 74, Campus Dom Bosco, CEP: 36301160, São João del Rei, MG, Brazil. \\ ${ }^{2}$ Universidade Federal do Mato Grosso do Sul, Campo Grande, MS, Brazil. \\ ${ }^{3}$ Universidade Federal de Minas Gerais, Belo Horizonte, MG, Brazil. \\ ${ }^{4}$ Independent Scholar, São João del Rei, MG, Brazil. \\ ${ }^{5}$ Corresponding author: Fernando Cesar Cascelli Azevedo, e-mail: fazevedo@ufsj.edu.br
}

\begin{abstract}
AZEVEDO, F.C.C., CANUTO, V., SOUZA, F., WIDMER, C.E. Puma (Puma concolor) predation on tapir (Tapirus terrestris). Biota Neotropica. 16(1): e20150108. http://dx.doi.org/10.1590/1676-0611-BN-2015-0108
\end{abstract}

\begin{abstract}
The process of forest fragmentation affects mostly top predators, which are more prone to first disappear. Pumas, Puma concolor, are known to have a generalist diet that includes a wide variety of wild and domestic prey species. The capacity of adapting their diet to consuming prey in anthropogenic habitats may be the reason for this species' success in incorporating anthropogenic areas with different levels of fragmentation as part of its habitat. Here we report a case of puma consumption of a large wild prey species, the tapir, Tapirus terrestris. From March 2012 to October 2013 we collected 85 puma's scats opportunistically inside fragments of the Atlantic Forest in the Parana state, Brazil. In one of the scats we found hairs and some hooves of a tapir, as well as puma hairs. We propose two hypotheses that may explain the occurrence of tapir in a pumas scat: (1) an event of scavenging or (2) an event of predation on a juvenile tapir. The most likely explanation for this event may be the predation of a juvenile in response to a possible abundant presence of tapirs in the study area. This event adds to our understanding of the great plasticity of this species to adapt to an altered landscape. To our knowledge, this is the first report of a puma scavenging or predation event on a tapir.
\end{abstract}

Keywords: predation, Puma concolor, scavenging, Tapirus terrestris.

AZEVEDO, F.C.C., CANUTO, V., SOUZA, F., WIDMER, C.E. Predação de anta (Tapirus terrestris) por onça-parda (Puma concolor). Biota Neotropica. 16(1): e20150108. http://dx.doi.org/10.1590/1676-0611-BN2015-0108

Resumo: O processo de fragmentação florestal afeta principalmente predadores de topo que são mais propensos a desaparecer. Onças-pardas, Puma concolor, são conhecidas por terem uma dieta generalistas que inclui uma grande variedade de presas silvestres e domésticas. A capacidade das onças de adaptar sua dieta ao consumo de presas presentes em habitats antropizados pode ser a razão do sucesso desta espécie em incorporar áreas antropizadas com diferentes níveis de fragmentação como parte de seu hábitat. Neste trabalho, nós apresentamos um caso de consumo de uma grande presa, a anta, Tapirus terrestres, por uma onça-parda. De março de 2012 a outubro de 2013 nós coletamos 85 fezes de onças-pardas de forma oportunista dentro de fragmentos de floresta Atlântica do estado do Paraná, Brasil. Em uma das amostras nós encontramos pelos e alguns pedaços de cascos de uma anta. Nós propomos duas hipóteses que podem explicar a ocorrência de uma anta nas fezes de onça-parda: (1) um evento de aproveitamento de carcaça ou (2) um evento de predação de uma anta jovem. A explicação mais provável para este evento de consumo é que se as antas ainda são comuns na região de estudo, um evento de predação pela onça sobre uma anta jovem pode ter ocorrido. Este caso acrescenta informações ao conhecimento da grande plasticidade das onças-pardas em se adaptar a paisagens alteradas. Este é provavelmente o primeiro registro de uma onça-parda consumindo uma carcaça de anta ou predando uma anta.

Palavras-chave: predação, Puma concolor, aproveitamento, Tapirus terrestris.

\section{Introduction}

The Atlantic Forest was one of the largest rainforests of the Americas, covering approximately 150 million hectares. Currently only $11.4 \%$ to $16 \%$ of the original forest remains, with more than $80 \%$ represented by fragments of less than 50 hectares in size (Ribeiro et al. 2009). This highly fragmented landscape affects mostly top predators and other large mammals, which are more prone to first disappear (Chiarello 1999). Considered the carnivore species with the widest distribution in the Americas, pumas are known to have a generalist diet that includes a wide variety of wild and domestic prey species (Currier 1983, Iriarte et al. 1990, Mazzoli et al. 2002, Azevedo 2008, Palmeira et al. 2008, Azevedo et al. 2010, Foster et al. 2010). 
The capacity of adapting their diet to consuming available prey present in anthropogenic habitats may be the reason for this species success in incorporating anthropogenic areas with different levels of fragmentation as part of its habitat (Lyra-Jorge et al. 2008, Miotto et al. 2011, Mioto et al. 2012). The dominant agricultural matrix may represent a greater availability of prey (Miotto et al. 2014) and the fragmentation process of native areas has also been altering the array of prey choices available to pumas. In such landscapes, greater predation rates upon capybaras, armadillos, snakes, birds and lizards has been reported, which seemed to be the more dominant prey species in such environments (Magioli et al. 2014). In addition, in times of scarcity of more vulnerable small and medium prey species, large prey species may become more important in the composition of pumas diet (Branch et al. 1996, Bank et al. 2002, Azevedo 2008). Fragmentation is also a wellknown factor for local extinction of jaguars (Panthera onca) (Gittleman et al. 2001) and the lack of this larger predator may be allowing pumas to exploit the empty functional niche (Azevedo 2008). If that is the case, pumas could eventually prey upon medium and large prey species known to be more present in jaguar's diet. However, data on the effect of habitat fragmentation on puma's diet are still scarce. Here we document a case of puma consumption of a large wild prey species, the tapir (Tapirus terrestris), which represents an event never previously reported.

\section{Material and methods}

Our research was part of a project conducted from 2012 to 2013 to investigate puma food habits in the southern part of the
Atlantic Forest in Brazil $\left(23^{\circ} 35^{\prime} \mathrm{S}\right.$ e $\left.52^{\circ} 20^{\prime} \mathrm{W}\right)$. Our study site was located on the northern part of Paraná State in a private area comprised of scattered fragments of Atlantic forest embedded in a matrix of agricultural land use interspersed with human habitats. Those fragments varied in size ranging from 0.2 to 2,300 hectares and were in most part connected to each other comprising a total area of about 5,000 hectares of forest. Most common mammal species in the area were agouti (Dasyprocta azarae), armadillo (Dasypus novemcinctus), capybara (Hydrochoerus hydrochaeris), coati (Nasua nasua), collared anteater (Tamandua tetradactyla), deer (Mazama sp.), paca (Cuniculus paca), rabbit (Sylvilagus brasiliensis) and tapir (Canuto 2014).

Only scats associated with puma's tracks close to the site of scat collection were considered puma's scats and were included in our analysis. Scats were dried at $72^{\circ} \mathrm{C}$ for $24 \mathrm{~h}$ and contents were separated under running water. Fragments were collected in a $600 \mu \mathrm{m}$ sieve. Food contents were identified to genus and species using hair, skull fragments, teeth, scales, and via comparison with reference material (Azevedo 2008). We prepared hairs and analyzed medullary structures and cuticular scale patterns following Quadros and Monteiro-Filho (2006 a). Once the hairs were prepared, we took microphotographs amplified 100, 200, and 400 times using a light microscope fitted with a digital camera. We tried to define the type of hair (overhair or underhair) analyzing two regions, the shaft and shield. To identify the species present in the scat we focused on the composition of hair microstructure (medulla, and cuticle).
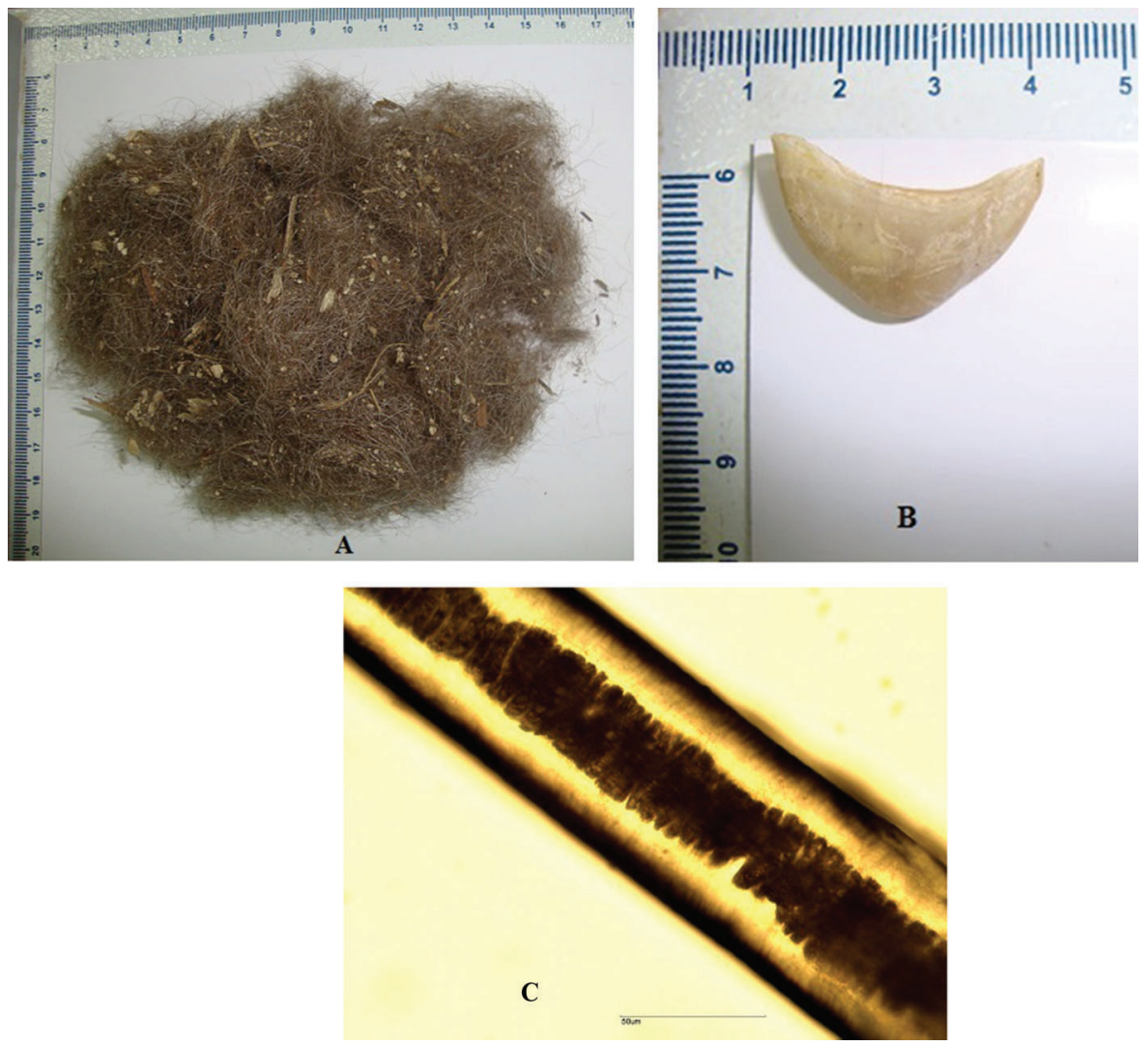

Figure 1. Hair, hooves, and microscopic structure of a puma's scat collected on the northern part of Paraná State along trails inside the study area from March 2012 to October 2013. (A) Hair contents of a puma's scat. (B) One of the juvenile tapir hooves present in the pumas scat. (C) Cloisonné medullar pattern on the shield of the juvenile tapir guard hair, amplified 400x. 


\section{Results and discussion}

We collected 85 puma's scats opportunistically along trails inside the study area from March 2012 to October 2013. After analyzing all the contents, we found hairs and some hooves on one of the scats that we couldn't identify as one of the regular prey species for pumas. The microscopic analysis revealed a great amount of juvenile hairs characterized by regular wave pattern suggesting the occurrence of a tapir (Quadros and Monteiro-Filho 2006 b). This general pattern could possibly confound the identification of a tapir for domestic horse. However, the shape of the hooves present on thet scat, which were small and whitish, indicated the occurrence of a juvenile tapir (Figure 1). We also found hairs supposedly from the predator. The microscope analysis revealed guard hairs with regular wave cuticular pattern and a very large cortex at the medulla (Figure 2), indicating the predator as a puma (Quadros and Monteiro-Filho $2006 \mathrm{~b}$ ).

Pumas are known to be generalist feeders and also scavengers (Bauer et al. 2005). Therefore, potential explanations for the occurrence of this species on puma diet are either an event of scavenging or an event of predation on a juvenile tapir. Due to the fragmentation of the original forest, the lack of a wide array of available prey species may have forced pumas to use whatever food resource was available in the region, and scavenging might be a reasonable alternative food source for pumas. Measuring the level of scavenging habits is crucial to estimate puma's energetic requirements (Elbroch et al. 2014) and would help to understand how these felids thrive on anthropogenic areas. The second possibility, a predation event on a juvenile tapir, may represent an alternative novel prey species in the puma's diet. Pumas and tapirs are sympatric species in geotropically forests (Azevedo 2008, Foster et al. 2010), however, puma predation on tapir has never been reported. Tapirs are prey for jaguars, which are larger in body size than pumas in places where they occur in sympatry (Taber et al. 1997, Garla et al. 2001, Cavalcanti and Gese 2010) whereas in other sites neither predator seemed to utilize tapirs as food source (Scognamillo et al. 2003, Novac et al. 2005, Weckel et al. 2006, Azevedo and Murray 2007, Foster et al. 2010). The large size of a tapir and the competition with

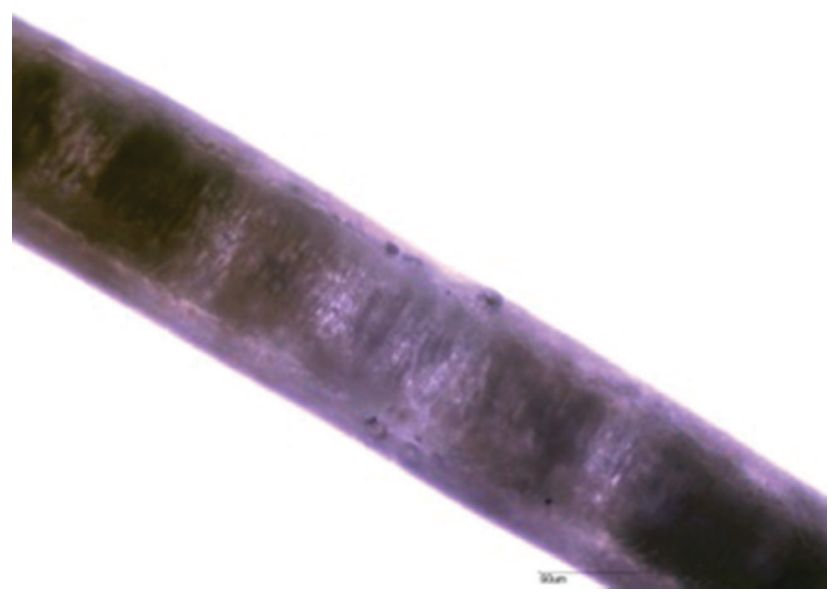

Figure 2. Microscopic structure of puma's hair collected in scat on the northern part of Paraná State along trails inside the study area from March 2012 to October 2013. jaguars seem to preclude puma predation on tapir. In most cases where the diet of pumas was recorded in fragmented areas, tapirs were no longer present in the landscapes and pumas utilized other available prey species (Magioli et al. 2014). However, in our study site, tapirs were still common and therefore, a puma predation event on a juvenile tapir may be another proof of the great plasticity of this species to adapt to an altered landscape. To our knowledge, this is the first report of a puma scavenging or predation event on a tapir.

\section{Acknowledgements}

We thank Companhia Melhoramentos Norte Paraná and ICMBio (Chico Mendes Institute for Biodiversity Conservation) for permission to conduct research in the study site. V.C.C. received a research fellowship from $\mathrm{CNPq}$ during the course of this study.

\section{References}

AZEVEDO, F.C.C. \& MURRAY. D.L. 2007. Spatial organization and food habits of jaguars (Panthera onca) in a floodplain forest. Biological Conservation 137:391-402, http://dx.doi.org/10.1016/ j.biocon.2007.02.022.

AZEVEDO, F.C.C. 2008. Food Habits and Livestock Depredation of Sympatric Jaguars and Pumas in the Iguaçu National Park Area, South Brazil. Biotropica 40:494-500, http://dx.doi.org/10.1111/j.17447429.2008.00404.x.

AZEVEDO, F.C.C., CONCONE, H.V.B., PIRES-DASILVA, A. \& VERDADE, L.M. 2010. Puma (Puma concolor) predation on a water buffalo (Bubalus bubalis). Mammalia 74:431-432, http://dx.doi.org/10.1515/mamm.2010.056.

BAUER, J.W., LOGAN, K.A., SWEANOR, L.L. \& BOYCE, W.M. 2005. Scavenging behavior in puma. The Southwestern Naturalist 50:466-471.

BRANCH, L.C., PESSINO, M. \& VILLARREAL, D. 1996. Response of Pumas to a population decline of the plains vizcacha. Journal of mammalogy 77:1132-1140, http://dx.doi.org/10.2307/1382795.

CANUTO, V.C. 2014. Ecologia alimentar da onça-parda (Puma concolor Linnaeus, 1771) em um mosaico de paisagem em mata atlântica do noroeste do Paraná. Dissertação, Universidade Federal de Mato Grosso do Sul, MS, Brasil.

CHIARELLO, A.G. 1999. Effects of fragmentation of the Atlantic forest on mammal communities in south-eastern Brazil. Biological Conservation. 89:71-82, http://dx.doi.org/10.1016/S0006-3207(98) 00130-X.

CURRIER, M.J.P. 1983. Felis concolor. Mammalian Species 200:1-7, http://dx.doi.org/10.2307/350395.

ELBROCH L.M., ALLEN, M.L., LOWERY, B.H. \& WITTMER, H.U. 2014. The difference between killing and eating: ecological shortcomings of puma energetic models. Ecosphere 5:53, http://dx.doi.org/10.1890/ES13-00373.1.

FOSTER, R.J., HARMSEN, B.J., VALDES, B., POMILLA, C. \& DONCASTER, C.P. 2010. Food habits of sympatric jaguars and pumas across a gradient of human disturbance. Journal of Zoology 280: 309-318, http://dx.doi.org/10.1111/j.1469-7998.2009.00663.x.

GARLA, R.C., SETZ, E.F. \& GOBBI, N. 2001. Jaguar (Panthera onca) food habits in Atlantic Rain Forest of Southeastern Brazil. Biotropica 33:691-696, http://dx.doi.org/10.1111/j.1744-7429.2001. tb00226.x.

GITTLEMAN J.L., FUNK S., MACDONALD, D.W. \& WAYNE, R.K. 2001. Carnivore Conservation. Cambridge University Press, Cambridge.

IRIARTE, J.A., FRANKLIN, W.L., JOHNSON, W.E. \& REDFORD, K.H. 1990. Biogeographic variation of food habits and body size of 
the American puma. Oecologia 85:185-190, http://dx.doi.org/10.1007/ BF00319400.

LYRA-JORGE, M.C., CIOCHETI, G. \& PIVELlO, V.P. 2008. Carnivore mammals in a fragmented landscape in northeast of São Paulo state. Biodiversity and Conservation 17:1573-1580, http://dx.doi.org/10.1007/s10531-008-9366-8.

MAGIOLI, M., MOREIRA, M.Z., FERRAZ, K.M.B., MIOTTO, R.A., CAMARGO, P.B., RODRIGUES, M.G., DA SILVA CONHOTO, M.C. \& SETZ, E.F. 2014. Stable isotope evidence of Puma concolor (Felidae) feeding patterns in agricultural landscapes in southeastern Brazil. Biotropica 46:451-460, http://dx.doi.org/10.1111/ btp. 12115.

MAZZOLI, M., GRAIPELB, M.E. \& DUNSTONEC, N. 2002. Mountain lion depredation in southern Brazil Biological Conservation 105:43-51, http://dx.doi.org/10.1016/S0006-3207(01)00178-1.

MIOTTO, R.A., CERVINI, M., BEGOTTI, R.A. \& GALETTI JR, P.M. 2012. Monitoring a puma (Puma concolor) population in a fragmented landscape in southeast Brazil. Biotropica 44:98-104, http://dx.doi.org/10.1111/j.1744-7429.2011.00772.x.

MIOTTO, R.A., CERVINI, M., KAJIN, M., BEGOTTI, R.A. \& GALETTI JR., P.M. 2014. Estimating puma (Puma concolor) population size in a human disturbed landscape in southeastern Brazil based on DNA-mark recapture data. Oryx 48:250-257, http://dx.doi.org/10.1017/S0030605312000841.

NOVACK, A.J., MAIN, M.B., SUNQUIST, M.E., \& LABISKY, R.F. 2005. Foraging ecology of jaguar (Panthera onca) and puma (Puma concolor) in hunted and non-hunted sites within the Maya Biosphere Reserve, Guatemala. Journal of Zoology 267:167-178, http://dx.doi.org/10.1017/S0952836905007338.
PALMEIRA, F.B.L., CRAWSHAW JR, P.G., HADDADC, C.M., FERRAZ, K.M.P.M.B. \& VERDADE, L.M. 2008. Cattle depredation by puma (Puma concolor) and jaguar (Panthera onca) in central-western Brazil. Biological Conservation 141:118-125, http://dx.doi.org/10.1016/j.biocon.2007.09.015.

POLISAR, J., MAXIT, I., SCOGNAMILLO, D., FARREL, L., SUNQUIST, M.E. \& EISENBERG, J.F. 2003. Jaguars, pumas, their prey base and cattle ranching: ecological interpretations of a management problem. Biological Conservation 109:297-310, http://dx.doi.org/10.1016/S0006-3207(02)00157-X.

QUADROS, J. \& MONTEIRO-FILHO, E.L.A. 2006a. Coleta e preparação de pelos de mamíferos para identificação em microscopia ótica. Revista Brasileira de Zoologia 23:274-278.

QUADROS, J. \& MONTEIRO-FILHO, E.L.A. 2006b. Revisão conceitual, padrões microestruturais e proposta nomenclatória para os pêlos-guarda de mamíferos brasileiros. Revista Brasileira de Zoologia, 23:279-292.

SCOGNAMILLO, D.G., MAXIT, I.E., SUNQUIST, M.S. \& POLISAR, J. 2003. Coexistence of jaguar (Panthera onca) and puma (Puma concolor) in a mosaic landscape in the Venezuelan llanos. Journal of Zoology 259:269-279, http://dx.doi.org/10.1017/S0952836902003230.

TABER, A.B., NOVARO, A.J., NERIS, N. \& COLMAN, F.H. 1997. The Food Habits of Sympatric Jaguar and Puma in the Paraguayan Chaco. Biotropica 29: 204-213, http://dx.doi.org/10.1111/ j.1744-7429.1997.tb00025.x.

WECKEL M., GIULIANO, W. \& SILVER, S. 2006. Jaguar (Panthera onca) feeding ecology: distribution of predator and prey through time and space. Journal of Zoology 270:25-30, http://dx.doi.org/ 10.1111/j.1469-7998.2006.00106.x. 